\author{
International Journal of Sustainable Development \& World \\ Policy \\ 2020 Vol. 9, No. 2, pp. 135-153. \\ $\operatorname{ISSN}(e): 2305-705 \mathrm{X}$ \\ $\operatorname{ISSN}(p): 2306-9929$ \\ DOI: $10.18488 /$ journal.26.2020.92.135.153 \\ (C) 2020 Conscientia Beam. All Rights Reserved. \\ check for
updates
}

\title{
THE ROLE OF WOMEN IN RURAL DEVELOPMENT IN ENUGU STATE, NIGERIA
}

\author{
Aguene, Ignatius \\ Nnamdi \\ Senior Lecturer Department of Sociology/Psychology Godfrey Okoye \\ University, Enugu, Nigeria. \\ Email:agueneignatiusnnamdi@gmail.com
}
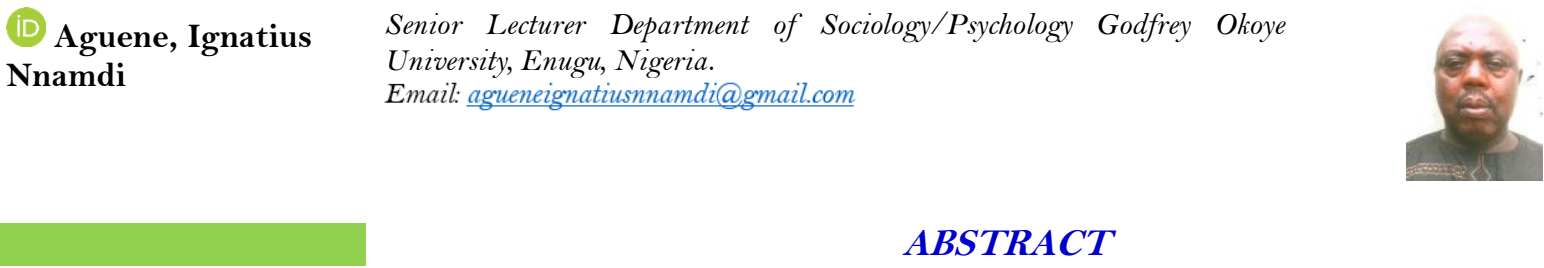

Article History

Received: 4 August 2020 Revised: 9 September 2020

Accepted: 23 September 2020

Published: 12 October 2020

Keywords

Role of women

Membership of corporative

organization

Women empowerment

Gender discrimination

Women education.

JEL Classification:

Rural Development

Women Empowerment

Women Organization

Cooperative Society

Economic Development.

\begin{abstract}
The study examined the implication of lack of women empowerment and nonmembership of organization in rural development in Nigeria. Specifically, the study investigated whether empowering women economically can increase their participation in rural development and whether women who belong to organizations contribute more to rural development projects more than those who do not belong to organizations. The ex-post survey method was adopted and 17 Local Government Councils in Enugu State were sampled. The respondents include 507 females and 458 males who were purposively selected from the sample areas through a multi-state sampling technique. Structured questionnaire was administered to elicit the desired responses. Data collected were processed through an econometric method that involves descriptive and inferential statistics. Findings from the study showed that women's rights much more than men's are routinely ignored and infringed upon at different stages of their lives despite constitutional guarantees. The study found that awareness campaign was the most influential factor motivating women to participate in community development and therefore should be encouraged. The study also found that membership of co-operative societies was a mobilizing factor in community development. Based on these findings, the study recommended amongst others, that women education should be encouraged to empower more women to contribute to rural development in Nigeria.
\end{abstract}

Contribution/Originality: This study is one of very few studies which have investigated the implication of women empowerment and membership of women organizations and cooperatives in rural development in Nigeria. The study provides empirical evidence that empowering women through education and membership of women organizations will enable them contribute more to rural development.

\section{INTRODUCTION}

Notably, rural people need water, food, good roads, empowerment, education, electricity, healthcare, decent housing, employment, entertainment, means of communication, facilities for social interactions and freedom from oppression etc. Rural electrification and improved sanitation are basic instruments in rural development. The later is a measure of rural living standards and the former will arrest emigration of the youths from the rural areas. If electricity is available, rural people can use electrical appliances and processing plants. Better storage, heating and cooling facilities as well as other attractive conditions can be made readily available to rural people (I. N. Aguene, 2004). After Nigerian independence in 1960 successive Nigerian governments used mobilization techniques. With 
the mobilization techniques, government realized that much could not be achieved for rural development, hence adopted self-help strategy. The meaning of self-help according to entails strategies that induce progress in rural societies, not all of which involve action by governments. It could be related to an individual who alone has the resources to implement a project or projects to satisfy the basic needs of a community. Similarly, it also implies coordinated efforts within a community to select and execute political, economic and social programmes addressed to the development of a community. According to Inhabekhai (2010) participation of the citizen facilitates growth and development in any community. It has obvious advantage to the individual and the community. These include:

i. It gives the individual a chance to participate in the socio-political process and economic development of his/her community, thereby improving process and capacity of choice.

ii. It arouses the consciousness of representative members in dealing with their common problems and satisfying their individual needs.

iii. It meets man's need for relatedness, for creativity, sense of belonging and for a frame of orientation toward a fulfilling future.

iv. Citizen participation as a process provides an opportunity for the participants to learn from each other, unlearn bad habits and learn new ways of defending their human rights and improving their lots and the living conditions in their society.

v. It allows for activity and involvement which encourage participants to widen their interests, acquire new skills of thinking, develop initiative and industry as well as discover inter-relationship that challenges attitude of community leaders.

vi. It gives training to democratic leadership and selection process.

vii. It promotes and strengthens community control, bringing about positive changes in the lives of the citizens and the communities in which the participants live.

viii. It promotes individual and collective responsibility in the community and is used to establish greater collaborative problem-solving mechanism among community leaders who have conflicting interest, diverse needs and rapidly changing and emerging programmes (Justice Development and Peace Commission, 1998).

The number of people involved in the process of production determines both the input and output in a given economy. Arisi and Agbure (2010) observed that a situation where a section of the society is denied equal participation in the process of development even though they are capable, will not speak well for sustainable development. Gender discrimination has been identified as placing limitation on a section of the society making it almost impossible for such group to be given opportunity to serve their father land.

According to Dokpesi and Ibezugbe (2010) the new thinking in community development literature is that for a community to develop, members should be encouraged to participate fully in issues that concern the improvement of their living conditions. The April 30 ${ }^{\text {th }}$ 2014 Supreme Court verdict on Igbo women's inheritance rights which set aside Igbo customary laws of inheritance, which deny women inheritance right is a step in the right direction. This is because no meaningful development can take place without the equal and full participation of both men and women. This is in line with the Igbo adage that when a child is treated like others the child will be happy.

In traditional Africa, African women were conditioned by tradition and the philosophy of the African traditional religion. Women were thought as only good in childbearing and rearing, cooking and feeding the entire family, giving only helping hands in agriculture and petty business. Thus their world was unfairly moderated by the men who looked down upon them because men made culture and custom to ensure their subordination. Men generally looked down on women as a group and individually. It was then fashionable for men to marry many women to boast their ego and even add concubines to the number of wives. They practiced gender oppression which resulted in denial for the female child both in inheritance and education. They engaged in genital mutilation of women to ensure that they reduce their sexual desire so that they will stay for them alone who have many wives and concubines. They have ritual of cleansing for women who have sex outside marriage and none for themselves. 
At the death of a man, his next of kin will inherit his wife, children and the property. If the wife opposes this arrangement she would be asked to go back to her parents.

However, with the coming of the colonial masters into Nigeria and the resultant social changes achieved mainly through western education and Christianity made the situation of women better than it was before. Western education made many people to change parochial way of reasoning while Christianity emphasized one man one wife and respect for wife as ordained by God. The situation of women became better than what it used to be before the coming of the colonial masters though still far from the ideal position. As a result of the social changes many men believe that two good heads are better than one in the family decision making but at the community level women as a group are still excluded from important decision making, though many still practice male child preference and disinheritance for women. The introduction of fundamental human right in the constitution stopped some dehumanizing practices against women (Ilogu, 1974).

Despite the contributions of women in the agricultural sector, their role in promoting economic growth and social stability continues to be inadequately recognized and undervalued. The following factors are responsible.

a. The male dominated culture in Nigeria which gives women an inferior position in the society.

b. Customs that forbid women from owning land, taboos, and the sexual division of labour which keeps women subordinate to men.

c. The problem of unpaid productive activities performed by women at the domestic front (National Gender Policy, 2006).

Nigeria is a highly patriarchal society, where men dominate all spheres of women's lives. Despite, a general commitment to the principle of non-discrimination as enshrined in section 2 of the 1999 constitution of the Federal Republic of Nigeria. Nigeria falls short of the desired result of giving males and females equal opportunities to advance socially, physically, educationally, politically and economically. Evidences abound that several negative aspects of gender relations, such as gender-based division, disparities between males and females access to power and resources, and gender biases in rights and entitlements, remain pervasive in Nigeria (National Gender Policy, 2006). Violence against women, particularly domestic violence and rape, is widespread and has increased the vulnerability of women to HIV/AIDs. Gender inequalities substantially limit women's access to control over, and use of services and productive resources. According to Okonkwo (2013) in Enugu like in most part of Nigeria, the democratic structure has not done enough to give women equal opportunities as men. This might explain why Nigeria especially South-eastern Nigeria has not developed her manpower and attained a remarkable economic status despite the abundant human and material resources, hence giving credence to the view that societies where women are not afforded equal rights as men can never achieve development in a sustainable manner (United Nations, 2008). Sustainable educational, political and economic opportunities are many a time given to men even when women are more qualified. When women are not given opportunities for career advancement and employment, their capacity for improving their monetary and economic scenario is restricted (Zinn, 2005).

Lack of economic empowerment and non membership of organizations by women all lead to low acceptance and support of women in community development projects resulting to inadequate participation of women.

\subsection{Objectives of the Study}

The general objective is to examine how lack of women empowerment and non membership of organization lead to inadequate participation of women in rural development. However, the specific objectives are to:

1. Examine whether empowering women economically can increase their participation.

2. Examine whether women who belong to organizations contribute more to rural development projects more than those who do not belong to organizations. 


\subsection{Research Questions}

In order to articulate the problems further, the following research questions were generated:

1. Does economic empowerment of women increase their participation?

2. Do women who belong to organizations contribute more to rural development than those who do not belong?

\subsection{Scope of the Study}

To find out the role of women in rural development, whether empowering women economically can increase their participation in rural development, whether membership of organizations increase the participation of women in rural development, the role of education in participation in rural development, reasons for inadequate participation of women in rural development were examined, the study looked at national gender policy and the efforts of the Nigerian government towards gender streaming, and the study made conclusion and recommendations.

\subsection{Significance of the Study}

The importance of this study will be measured on the theoretical and practical levels. On the theoretical level, the findings of the work will contribute to knowledge on women participating in rural development. Specifically, the study will provide information on leading factors, economic empowerment of women and women membership of organizations. The study will equally be very important in highlighting the implications of the internalization of low status given to women. On the practical side, this work will be useful for policy makers involved in formulating policies on women's contribution to rural development, not only in Enugu State but Nigeria at large. Also information provided by this study will make the government and other agencies to pay more attention to some of the issues raised about unequal participation of women in rural development, and its hindrance to sustainable rural development and take immediate measure towards addressing them. The findings will also be useful to those formulating policies and programmes to improve rural areas in Nigeria. This study will have important policy implications for women liberation and gender issues in Nigeria and will help in formulating policies that will have positive impact on the participation of women in rural development. Hopefully, in the future, this research shall form the basic material of reference for further research on women throughout rural Nigeria, and possibly Africa. Finally, the study will help to enhance the rural women's capability and their decision-making status both in the family and society at large.

\subsection{The Role of Women in Rural Development}

According to Idriss (1992) official statistics rarely makes any effort to measure it, even though it is more than clear that not just unpaid household work but the farming and trading activities of women that make a significant contribution to the well-being of poor rural households. All the evidence suggests that the poorer the household, the more hours women work and the greater their investment in both economic production and family welfare. From a situation of multiple disadvantages often as single parents, women can move to one in which they contribute and benefit three - fold - in the home, in society at large and, not least in the development of the next generation.

\subsection{Agriculture}

Women form the bulk of peasant farmers in the rural areas who feed local communities and the teeming population of the cities. According to Okeyo (1979) agricultural work done by women includes pre-planting activities, such as land preparation, digging and ploughing, followed by planting the seeds, cutting grasses and trees, hoeing and weeding. Women account for between 60 to 80 percent of agricultural labour force in rural areas 
in Nigeria. According to Onokerhoraye and Okafor (1994) in the case of women the combination of farm and household responsibilities may amount for as many as 15 hours or more. Rural women do not have the luxury of coming home from work and putting their feet up to rest. Straight from the farm, there are children and household chores to attend to. Even at bedtime; they are disturbed by men with sexual requests and advances. Processing of food is the preserve of women. They process cassava into Garri, Fufu or Abacha or flour; maize into flour or Akamu. Cocoyam can be dried and grounded into flour and host of other crops.

\subsection{Animal Husbandry}

I. N. Aguene (1998) observed that women often gather leaves and other items that animals feed on. Their work also includes grazing sheep and goats and in some places, cattle which means women trekking long distances in search of pasture or water. In the case of cattle, women milk them and do other preservation processing that might be required in both agriculture and animal husbandry. In some areas, women own animals either by buying them or through arrangements to rear female animals for somebody so that if the animals reproduce, they could share proportionally.

\subsection{Women Organizations and Agriculture}

Mabonje (1991) observed that the Better Life Programme which was launched in 1987 as well as the Family Support Programme of the Abacha administration did a lot to enhance women's participation in development process. In spite of their attendant circumstantial and congenital constraints, some specific achievements can be attributed to the programmes in some parts of Nigeria.

\subsection{Distributive Trade}

In a number of African countries, notably Ghana, Nigeria, Sierra Leone and Benin, the role of market women has been well documented. In these places, they account for up to 80 percent of trade in foodstuffs and the provision of rural areas with essential commodities (Onokerhoraye \& Okafor, 1994). Women are mostly responsible for effective distribution and supplies of goods, particularly food items and services to and from the cities. Thus, women play indispensable roles in the commercial life of nations. Where women are secluded, they process foodstuffs and other items for their little children to sell for them. Women also dominate such industries as pottery, cloth weaving and catering services in most rural areas.

\subsection{Health Services}

Aguene (1998) noted that women play very important roles in the environmental sanitation of the rural societies by keeping homes, village squares, village shrines, market places, churches, and other social centres cleanthereby playing indispensable role in enhancing the public health of the rural communities. Many of the nurses, midwives and other para-medical staff in the dispensaries, health centres and hospitals in most rural areas are females.

\subsection{Strategies for Improving Women's Participation in Rural Development}

According to Nyerere et al. (2014) the role of education in sustainable development is so crucial that the United Nations designated the decade between 2005 and 2014 as the UN Decade of Education for Sustainable Development. UNESCO (2004) notes that education for sustainable development implies integrative sustainability issues in teaching and learning such as climate change, disaster risk reduction, poverty reduction and sustainable consumption. Sustainable development requires a participatory type of teaching and learning that motivates and empowers learners so as to change behaviour and take action for sustainable development. It is evident here that United Nations sees education as a tool for spurring sustainable development. According to (Onah, 2011) 
themes on good governance should be part of primary, secondary and tertiary institutions curricular in Nigeria. Topics such as electoral rights and processes, and gender equality should be taught. This will help in raising individuals that are gender sensitive, individuals who see people in their own rights as human beings not male being superior to females. Modern agents of socialization such as schools, churches, mass media, and other organs of social communication should be used to educate women on the United Nations declaration on human rights especially the -important sections concerning women's' rights.

According to Adebisi and Ademola (2014) Participation means the active involvement of communities in needs assessment, determination of priorities, planning and execution of projects. It also refers to the contribution of potential beneficiaries to the realization of a project for their own development (Mansuri \& Roa, 2004). In order to bridge the gap between the local government authorities and the local communities, there is the need for incorporation of the local knowledge into the projects' decision making process (Nwankwo \& Ezeh, 2007). According to Olabode (2012) If the factors that are responsible for gender marginalization persist, Nigerians quest for accelerated development may be impeded because a number of MGDs goals targeted the womenfolk, he recommended that to attain these goals, there is need for both men and women to be adequately part of decision making at all levels of government. This will guarantee the representation of gender issues as they affect both sexes. According to Nweze (2011) achieving gender equality will require a commitment to implement effective programmes and policies, especially those at the community level. Investments are proven strategies that promote gender equality. Education and skills training must be backed with adequate funding. New gender policies addressing women's economic and social vulnerabilities in a number of new initiatives, including the Milliennmm Challenge Account, offer promise, but they will need dedicated resources to materialize. Also, the Beijing Platform for Action recognizes that women's full representation and participation in decision are making positions in government; policy making positions in government, policy making and political parties could act as a means of accelerating the transformation of economic, social and political power relations in societies. Disaggregating political participation by sex provides insight into the gender gaps that exist in governance in Nigeria. According to China Today (1995) Chinese women have equal rights with their male counterparts politically, socially, economically and culturally. Similarly they are on a par with men both at home and in society.

Another area where feminism becomes relevant and will create awareness according to Onwe (2008) are:

1. Creating strategy for safe mother hood, which will help to reduce the risk of septic abortions, school regulations in certain places might be changed to stop the expulsion of pregnant girls.

2. Creating laws by rising the legal age of marriage for girls EI (Hinawi, 1991).

3. Improving legislation and policy on maternity leave and working conditions for pregnant women, this will make an important contribution to safe motherhood and improve maternal as well as child health.

4. Bringing to the fore the review of marriage, divorce and inheritance laws, especially customary laws which have much to do with women's economic, social and psychological status and thus with their health.

5. Helping to review laws or policies that discriminate against women in the area of civil rights for example, the right to vote keeps them from having a voice in decisions that are crucially important to them, and keep them from making their full contribution to development.

Adigwe (1982) noted that women are the bedrock of agricultural activities and ways of improving their economic life and that of the country include the following.

1. Introduction of co-operative societies in various local governments and communities and women should be encouraged to be members.

2. Location of art and craft centres in various communities and equipped with modern Machines to enable them produce their craft in an open market. 
Provision of machineries for clearing, ploughing and harrowing for the local women so that human labour will be minimized.

The National Policy on Women noted that "affirmative action of proportionate ratio or 30\% representation will be employed to increase the total representative seats in each of the legislative houses, executive arms, and party hierarchy. This shall be reserved for women for a trial period up to the year 2010 (National Gender Policy, 2000).

That policy is in fact already outdated in the International World because at the UN Conference on Women in 1995 held in Beijing, China, the achievement of the threshold of 30\% was by the year 2000AD. All the Nations of the World, including Nigeria accepted this being signatory to the Beijing Declaration and Platform of Action. The UN and all the 167 Nations accept that the best indicator to ensure larger proportion of the female gender.

Despite unprecedented human development efforts in the past three decades, a wide-spread pattern of inequality between men and women still persists. This is the result of centuries of neglect to focus on gender issues. In the developing world in particular, where women have been regarded as non-persons for generations, progress towards achieving recognition has been slow and progress towards achieving gender equality has been slower. This has affected development adversely. The term "development" was first identified as an issue during the World Conference on Women celebrating the International Women Year in 1975. At the conference in Mexico, factor such as the inequality of decision-making in the family was identified as one of the constraints to women's participation in development. Such was the enormity of the problems faced by women that the Conference recommended the declaration of a decade for women, during which development policies and programmes will take women into consideration as people. Gender bias has been discovered as placing limitation on section of the society making it almost impossible for such group to be given opportunity to serve their father land and the effect of this bias is mostly suffered whether civilized or not. In addition, most United Nations organization and specialized agencies have developed programmes for women over the years. Special attention to the issue of women's role in development has always been necessary because many women continue to experience limited access to essential resources. Hence legal and institutional structures need to be reformed in order to guarantee women equal rights and responsibilities, including decision making at all levels. Although the gender gap has narrowed slightly in public life and leadership position, the record of women in decision making, management position and economic decision making worldwide has remained poor.

The structures and issues that need constitutional review in this regard according to Akanda (2009) include:

- The excessive emphasis on the application to tradition, culture and religion which ensures that women are perpetually kept in a position socio-economic rights which put them at a great disadvantage against the other gender.

- $\quad$ The language of the text of the Constitution which perpetuates the assumption that the males are the only ones recognized by its provisions. The psychological effect of this on women's participation will require research.

- $\quad$ The composition and constitution of political parties. This is where the marginalization of women begins within the political process.

- $\quad$ The need for affirmative action clauses to address historical discrimination and injustices against women, for if the issue of minorities can be addressed by the federal Character provisions, the issue of gender-sensitiveness can be address by Social Justice Provision.

According to Obi (2010) in Israel, collective Jewish settlements are called kibbutzim. The Kibbutz (the singular form, is important for gender research because gender equality is one of its goals, with men and women sharing in both work and decision making. Members of kibbutzim consider gender irrelevant to most of everyday life. Both men and women take care of children, cook and clean, repair buildings, and make day-to-day decisions concerning life in the kibbutz. Girls and boys are raised in the same way and from the first weeks of life, children live together in dormitories. Women and men in the kibbutzim have achieved remarkable (although not complete) social equality. Thus, kibbutzim are evidence of the wide latitude that culture has in defining what is feminine and what is masculine (Obi, 2010). 
The Beijing Platform for Action adopted at the fourth world conference on women at Beijing on $15^{\text {th }}$ September 1995 was the first international policy framework that talked about genders in relation to ICP. A very good example is the women of Uganda network. Sources of intervention strategies for the eradication of unhealthy widowhood practices that can usher in sustainable development in Nigeria and other African nations included. According to Oduara (1994)

- $\quad$ The use of traditional rulers in whose domains, most times, these discriminatory inhuman practices occur. Due to modernization they should issue pronouncement revoking those dehumanizing practices earlier mentioned.

- Through religious bodies to propagate creeds that will guide adherents in their daily interactions with fellow human beings.

- $\quad$ Mass media are effective means of influencing change. Through jingles in about 400 indigenous Nigeria languages along with an expanded Nigerian pidgin, women will be sensitized to know and uphold their human rights and will also be equipped with information that can be translated into economic power for sustainable development.

- The use of advocacy groups: according to Owen (2001) bodies like Empowering Widows in Development (EWD), Widows for Peace and Empowerment (WFPC) which were established in 1996 and 2001 respectively, and other emerging human rights and women's rights organizations must continue to address the endemic problem of disinheritance, discriminations sexual abuse and other unwholesome practices on widows. Initiatives that seek to support the liberation of the widow from the shackles of poverty and oppression should be encouraged by the local, state and federal levels of governance.

- Through Education: Knowledge indeed is power. Women should access this power through the appropriate education of the girl-child. Where she is so empowered, she becomes automatically liberated and her potentials for development can thus be adequately exploited.

Rural access programmes to develop and improve information and communication system to enable easy access to timely market information for rural women needs to be increased. Lack of information has been identified as a key limiting factor to increased productivity in rural communities. Rural farmers lack information on how to improve quality of their produce, improved seeds and crop varieties, source of inputs/implements, control plant diseases, pests; and their information has limited the production levels of the rural women farmers, hence limiting their incomes (Olisa \& Obiuku, 1992).

Despite the conception that women engage in solely domestic activities which require lower level of skill and innovation, NGOs and policy bodies are beginning to recognize and highlight the knowledge, innovation and abilities possessed by women. As a result, experts have identified four priority areas: supporting electronic networks, promoting strategic use of information and communication technologies among partner communities, developing information content and tools, lobbying and advocacy. While its recommendations do not focus solely on women, the importance of supporting women's participation in these areas is clearly stated as an important issue for the "Africa Information Society" (UNAPC, 1997). Hence, gender equity is an essential building block in sustainable rural development. Accordingly, no development can be achieved without solving the prevailing problem of gender inequity (Towards Earth Summit, 2001).

Furthermore, sustainable rural development is contingent upon the three pillars of: environmental protection; economic well-being and social equity. In other words, we say development is being sustained to the extent to which citizen enjoy environmental protection, economic well-being and social equity. That is, we measure sustainable development with the above mentioned factors. In order to achieve the above in an economy, it requires the full and equal participation of women at all levels. This is because, it is clearly inappropriate to try and address problems, to identify the appropriate strategies or to implement the solution if only half of the people concerned are involved in the process. Hence, gender equity is an essential building block in sustainable development. According to the social Briefing of the World summit none of the three "pillars" of sustainable development can be achieved without solving the prevailing problem of gender inequity (Towards Earth Summit, 2001). 


\subsection{Objectives of Women Education}

United Nations Education Scientific and Cultural Organization UNESCO (1995) outlined the main objectives for women education as follows:

1. To enable women to improve their family health and diet.

2. To increase Women's productive ability, thus raising their family's standard of living.

3. To give women access to appropriate technologies, management of cooperatives.

4. To improve women's societal and cultural status.

5. To enable women, discharge their responsibilities more effectively.

6. Helping women to fight their own fears and feelings of inadequacy or inferiority.

7. Educating women in all round development that is mentally, socially, physically, psychologically, religiously and economically e.tc.

Thorton (1982) argues that it is the nation or society that blends the strengths of women and men that will lead the world into development in all the fields or sectors. In order to blend the strengths of both sexes for development, entrepreneurship development is a crucial tool for economic empowerment especially for the women folk. The need to develop women entrepreneurship was emphasized in UN Conference on Women (1995) at the Fourth World Conference on Women. The objectives were to:

(a) Increase the participation of women in industry and all other sectors, particularly in the non-traditional areas, through access to advanced technology.

(b) Promote support, and strengthen female entrepreneurship development.

(c) Encourage investments in environmentally safe products and environmentally sound and productive agriculture, fisheries, commercial and industrial activities and technologies; and

(d) Strengthen training opportunities for women.

In Nigeria, there have been many bold attempts by government to appropriately energize the small and medium Enterprise sub-sector to serve its catalytic role in economic development of the country hence the establishment of the following organizations;

(a) Bank of Industry (BOI) established in November 2000.

(b) Small and Medium Industries Development Agency of Nigeria (SMIDAN) established in 2000.

(c) The establishment of Small and Medium Industries Equity Investment Scheme (SMIEIS) established in August 2002.

(d) Nigerian Agricultural and Cooperative and Development

Bank (NACRDB) established in the year 2000.

(e) Micro Finance Bank established in 2005.

Some of the objectives of these banks are;

(a) Fund mobilization,

(b) Enterprise promotion and development

(c) Designing, packaging and promoting cottage/micro and small-scale industries

(d) To make the Banking Industry contribute towards the effort of the Federal Government in stimulating economic growth, developing local technology and generating employment

Finally, the Micro Finance Bank is established for about $65 \%$ of Nigerians who are poor and who do not have access to the formal financial system.

According to Olakorotu (2013) several reasons compelled women to stay in abusive relationships. The major reasons include economic security, sake of children, fear of reprisal by society, fear of further abuse and the normalization of abuse by the society. Society and men in particular need education on the rights of women and the consequences of wife battering. There is need for programmes for identifying and empowering women in abusive relationships to confront the challenge. Counseling rural women on entrepreneurial 
opportunities provide them with knowledge and competence that will enable them to strive favorably in the rural community. Women generally play vital roles in family economic advancement: they need to be properly groomed with entrepreneurial skills in order to harness these opportunities in the rural areas. Therefore, rural women embrace entrepreneurship for the survival and better living. Government organizations and private donors should assist our rural women to gain access to soft loans to improve their businesses.

\section{REVIEW OF RELEVANT THEORIES}

\subsection{Gender Role Socialization}

Socialization is the process by which people learn the expectations of society. Roles according to Aderson (2009) are learned through the socialization process and are the expected behavior associated with a given status in society. Through socialization, people absorb their culture-customs, habits, laws, practices, and means of expression. Socialization also establishes personality, defined as the relatively consistent pattern of behavour, feelings, and beliefs of an individual. Women and men encounter different socialization patterns as they grow up because each gender brings with it different social expectations.

Through socialization, people internalize cultural expectations, then pass these expectations on to others. Internalization occurs when behaviours and assumptions are learned so thoroughly that people no longer question them, but simply accept them as correct. Through socialization, one internalizes the expectations of society. The lessons that are internalized can have a powerful influence on attitudes and behaviour. However, people can change the cultural expectations they learn. New experiences can undermine narrow cultural expectations. Berger (1963) pointed out that not only do people live in society, but society also lives in people. Socialization is, therefore, a mode of social control. Socialization emphasizes the adaptations people make as they learn to live in society. Socialization is a life-long process with consequences that affect how we behave toward others and what we think of ourselves (Macionis, 2015).

Socialization creates the tendency for people to act in socially acceptable ways. Through socialization, people learn the normative expectations attached to social situations and the expectations of society in general. As a result, socialization creates some predictability in human behavior and brings some order to what might otherwise be social chaos. When people are simply doing what they consider "normal," they are communicating social expectations to others. People feel pressure to become what society expects of them even though the pressure may be subtle and unrecognized (Macionis, 2015).

Through socialization both girls and boys internalize cultural expectation which leads to deprivation for the girl child. Gender oppression is internalized and it becomes normal and this leads to mind-set because it has always been like that. The internalized norms and values make women believe that men are superior to them. This postulation is supported by lack of inheritance rights among the Igbo women.

Socialization is a mode of social control because socialized people conform to cultural expectations. This is one of the reasons some women given the questionnaire to fill rejected sharing decision making equally with their husbands and inheriting from their late father's property for fear that it might lead to tension in the family.

Socialization affects how we behave towards others and what we think of ourselves. This has made women have a lot of respect for men. People feel pressure to become what society expects of them even though the pressure may be subtle and unrecognized, for instance, the pressure to respect men. There is the need for awareness campaign, economic empowerment and proper education. This is because people can change their cultural expectations when they learn new experiences (Otite \& Ogionwo, 1979).

\subsection{Conflict Theory}

Karl Marx (1818-1883) was the originator of conflict theory. The basis of Marx's sociology is materialism where economic factors determine every other sphere of life. There are two traditions of conflict theory. 
Ralf Dahrendorf, Lewis Coser and Randall Collins according to Wallace and Wolf (1982) can be grouped as analytic conflict theorists because they share the belief that a conflict perspective is central to the development of an objective or scientific sociology.

Where functionalists emphasize the orderliness of society, conflict theorists see dissension and conflict at every point in the social system; the exponents of conflict theory see many societal elements as contributing to disintegration and change.

Feminist theory refers to analyses that seek to understand the position of women in society for the purposes of bringing about liberating social changes. Feminist theory assumes that the theory is important, not just because it analyzes gender and society, but because it also assume that change is essential to make fully equal citizens. Underlying feminist theory is also the idea that gender relations are fundamental to how society has been organized and understanding how this is so critical to the successes of the feminist movement. The very relevance of women studies stems from the contents of its investigation, which has given meaning to feminism. Feminism which have been identified as the belief and aim that women should have the same rights and opportunities as men and the organized movement which promotes equality for men and women in political, economic and social spheres have a range of relevance to women studies (Onwe, 2008).

\subsection{Theoretical Framework}

Having reviewed gender role socialization, and conflict theory-feminist perspective, the researcher adopted the conflict theory from the feminists perspective as the theoretical framework of this study; and this bothers on gender discrimination and sub-optimal participation of women in rural development.

The differential distribution of authority becomes the determining factor of social conflict. This is because those in dominant positions seek to maintain the status quo while those in subordinate positions seek change. However, conflict can lead to consensus and integration. The more elastic systems allow for open and direct expression of conflict within and they adjust the balance of power, and they are less likely to be menaced by explosive alignments. Power is unequally distributed and those who have great deal of power must be obeyed. In a situation of inequality, those groups that control resources are likely to exploit those that lack resources. Conflicts are unhealthy competition for power, resources and interests. By its very nature, conflict is counter productive. For example, gender inequality denies communities sustainable development.

Although people who consider themselves feminists disagree about many things, most would probably support five general principles (World Bank, 1995).

- The importance of change is critical of the statuesque advocating social equality for women and men.

- Expanding human choice the female world of emotion and cooperation and the male world of rationality and competition. As an alternative feminist pursue a reintegration of humanity by which each person develops all human traits.

- Eliminating gender stratification feminists oppose laws and cultural norms that limit the education, income and job opportunities of women.

- Ending sexual violence, a major objective of today's women's movement is eliminating sexual violence. Feminism argues that patriarchy distorts the relationship between women and men encourage violence against women in the form of rape, domestic abuse, sexual harassment and pornography.

This imbalance of power between women and men is greatest in developing countries like Nigeria (Ilo, 2005). It has been widely demonstrated that poverty accelerates and increases gender inequalities; agriculture predominates in developing countries attracting under-privileged people in this respect. It follows that this represents a repository of poor people and it can be assumed that poverty is associated with extreme forms of gender inequality. This can be related to the women who participate in rural development of the developing nations, where there is reduced self-actualization occasioned by their global placement in the rural areas. This explains why 
local women are most often in the weakest and poorest circumstances are not participating optimally in rural development, in the remote regions of underdeveloped nations.

\subsection{Research Hypotheses}

Following from the theoretical framework, the following hypotheses were formulated.

1. Lack of economic empowerment of women result in inadequate participation.

2. Women who do not belong to organizations result in inadequate participation of women.

\section{RESEARCH METHODOLOGY}

\subsection{Area of the Study}

The study was conducted in Enugu State which was created from old Anambra State on $27^{\text {th }}$ August, 1991. It has a total land mass of 7161 square kilometers it is within latitude 6.6095187 and longitude 7.3516558 . Geographically, Enugu State is situated on much of the highlands at Awgu, Udi and Nsukka hills and the rolling low lands of the Ebonyi River Basin to the East and Oji River basin to the West. It is located in the South Eastern region of Nigeria with seventeen (17) local government areas. It is bounded by six other states: Abia and Imo in the South, Benue and Kogi in the North, Ebonyi and Anambra in the East and West respectively (Ntunde, 2004).

\subsection{The Population of the Study}

The study covered the seventeen (17) local government areas (LGAS) that make up Enugu State. The entire male and female population consisted the population of this study including those that reside in the urban areas whether indigenes or not. The total population of the seventeen local government areas is: three million two hundred and fifty seven thousand two hundred and ninety eight 3,257,298 (National Gender Policy, 2006). The age range is 20 years and above which includes indigenes and non-indigenes without regard to socio-economic status.

\subsection{Determination of Sample Size}

Applying the Yamane model to the present study we have:

$\frac{3257298}{1+3257298(0.05)^{2}}=\frac{3257298}{1+8143.245}=\frac{3275298=\mathrm{n}=399.95=400}{8144.245}$

However, the sample size of 400 was increased to 999 by cluster method because the large population 3257298 of the state made up of 17 local government areas with 230 communities could not be covered adequately with sample size of 400 . Therefore the sample size of this study is 999 .

Borley (1971) proportionate allocation formula was used in determining the number of questionnaires to be allocated to each of the sampled LGAs because of the differences in the number of female and male residents. The formula as quoted in Krishmaswany (2005) is the sample size for the study is 965comprising 507 females and 458 males. Out of 999 questionnaires were distributed, 34 were not returned or found useful.

\subsection{Sample Techniques}

A combination of several sampling techniques was used. The cluster sampling technique was used. This was done by clustering the seventeen local government areas into three senatorial districts - Enugu East senatorial district, Enugu North senatorial district, and Enugu West senatorial district. This clustering was to enable the researcher achieve efficiency and representativeness. From these clusters, two local government areas were selected through the hand drawing method of the simple random sampling. The selected six local government areas have a total eighty one communities which is high considering time, money and other logistics involved. Thus, the researcher reduced the number of the communities to twenty four; four from each local government area, using balloting method of the simple random sampling. After working out the sample size per local government area 
selected, the four communities per selected local government area irrespective of the number of communities in each selected local government area. The actual communities were selected through lucky deep sampling method.

Cluster sampling techniques was used before they were randomly selected. Within each community, cluster method was used to allocate ten associations and groups to each community. In each community the total number of associations and groups were gotten from the ward councilor. While systematic random sampling was used to pick the respondents from the lists of registered members of associations and groups. In the selected communities in each selected local government area, the list of registered association and groups were used to select the respondents. The study applied systematic random sampling method to select respondent from registered groups and associations. The stratified random sampling was used to choose the sample size to be administered with the research instrument. The stratified random sampling technique was used because it allows the researcher to select the elements to be included in the sample on the basis of their special characteristics as they were related to the study. The selection of the respondents for in-depth interview was based on who was the leader of a particular group. That is any group that was chosen for the study. The other set of people interviewed were the management staff of the community development office of the selected local government areas. Three staffs were selected in order of hierarchy making a total of eighteen management staff. This was done to obtain information on the work and experience of the administrators in rural development. Presidents of town unions of the selected communities were interviewed together with other key informants. Total of 52 respondents were used for in-depth interview for the study. Purposive sampling ensures that only respondents that satisfy the specific need of the researcher are included in the sample. The problem however, with the technique is that typicality of the sample is only assured by the researcher which imposes limitation on the generalizations to be made (Krishmaswany, 2005).

The questionnaires were given to the members of registered associations and groups who were selected through systematic random sampling in their association's secretariat or venues for meetings. The questionnaires were administered to selected members during their meetings. Respondents not reached during the first meeting were given on the next meeting day. Across the associations, meetings were mostly held once or twice a month on specific native days. In-depth interviews were conducted face-to-face, while use of local language was adopted where necessary, as a medium of communication to reduce ambiguities and was finally translated into English language. In addition to taking notes, tape recorders were used which enabled researcher to ensure that exact response were collected and transcribed. The two methods were done with the help of research assistants.

Standardized questionnaire used for data collection in the study comprised thirty five questions. The questions were such that reflects the objectives, research questions and hypotheses of the research. The questionnaire was divided into two section of close ended and open ended. In distributing copies of the questionnaire twelve research assistants who are graduates of the social sciences programme were engaged. Two research assistants were assigned to one local government area. The research assistants were chosen and trained in back translation methods based.

\subsection{Validity and Reliability of Research Instrument}

The study used content validity. Validity of an instrument refers to the ability of the instrument to measure what it purports to measure. Reliability is concerned with the stability, dependability and predictability of an instrument. Two hundred (200) questionnaires were distributed to the six local government areas selected through cluster method and systematic random sampling. Systematic random sampling method was used since the study was interested in members of registered associations and groups. The modified questionnaires were given to some respondents with the help of research assistants who were trained in back-translation method. After two weeks elapsed, the research assistants issued the same questionnaire the second time to the same respondents. The two results were compared to determine the degree of consistency. To test for the reliability of the instrument, the Pearson Moment Correlation Coefficient was used. This essentially involves examining the correlation between the 
responses of the respondents from a pilot study from the two groups of respondents. A correlation above 0.5 indicates reliability while a correlation coefficient below 0.5 indicates no reliability.

\subsection{Method of Data Presentation and Analysis}

Descriptive and statistical tools such as simple percentages, frequency distribution and tabular presentation were first used to analysis the data. The second stage was the testing of hypotheses. In analyzing the data collected from the field survey and to test the formulated hypotheses for the study chi-square $\left(\mathrm{x}^{2}\right)$, statistical tool was used, it is stated thus:

$\mathrm{X}^{2}=\underline{\Sigma(\mathrm{O}-\mathrm{e})^{2}}$

The above frequencies are the responses from the structured questionnaires administered to respondents, which were presented on the contingency table. The level of significance used was $5 \%$.

The degree of freedom is calculated as

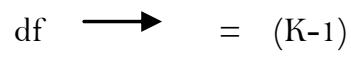

Where $\mathrm{df} \longrightarrow$ degree of freedom.

$\mathrm{K}$ number of rows or columns.

The chi-square test was used to determine the association among variables identified in the study. This was useful in explaining the relationship between the dependent and independent variables. Percentages and graphic illustration were used presenting the issues identified in the study for clearer understanding. Responses from the indepth interview were transcribed verbatim. Transcripts in Igbo language were translated into English language. Themes that emerged from the data were identified according to issues investigated and reported accordingly.

\section{RESULTS ANALYSES AND INTERPRETATION}

4.1. Economic Empowerment of Women Increase Women Participation in Rural Development

Table-1. Does economic empowerment of women increase women participation in rural development?

\begin{tabular}{|c|c|c|c|c|c|c|}
\hline \multirow{2}{*}{$\begin{array}{c}\text { S/No } \\
\text { Qs } \\
\end{array}$} & \multicolumn{2}{|r|}{ Yes } & \multicolumn{2}{|r|}{ No } & \multicolumn{2}{|c|}{ Do not Know } \\
\hline & No & Percentage & No & Percentage & No & Percentage \\
\hline 11 & 698 & 72.3 & 246 & 25.5 & 21 & 2.2 \\
\hline 12 & 702 & 72.7 & 240 & 24.9 & 23 & 2.4 \\
\hline 13 & 935 & 96.9 & 16 & 2.7 & 14 & 1.5 \\
\hline 14 & 952 & 98.7 & 9 & .9 & 4 & .4 \\
\hline 15 & 937 & 97.1 & 19 & 2.0 & 9 & .9 \\
\hline 16 & 779 & 80.7 & 163 & 16.9 & 23 & 2.4 \\
\hline 17 & 819 & 84.9 & 125 & 13.0 & 21 & 2.2 \\
\hline 18 & 562 & 58.2 & 393 & 40.7 & 10 & 1.0 \\
\hline Average & 798 & 82.8 & 151 & 15.3 & 16 & 1.6 \\
\hline Total & \multicolumn{6}{|c|}{$965=100 \%$} \\
\hline
\end{tabular}

Average result of table above indicated that majority of the respondents 798 representing $82.8 \%$ said yes that the economic empowerment of women can improve the participation of women in rural development. However, 151 respondents representing $15.3 \%$ said no but 16 respondents representing $1.6 \%$ did not know. The details are as follows: 
4.2. Women Who Belong to Organizations Participate More in Rural Development Projects

Table-2. Does membership of women organisation increase women participation in rural development?

\begin{tabular}{c|c|c|c|c|c|c}
\hline S/No & \multicolumn{2}{|c|}{ Yes } & \multicolumn{2}{c|}{ No } & \multicolumn{2}{c}{ Do not Know } \\
\hline Qs & No & Percentage & No & Percentage & No & Percentage \\
\hline 19 & 762 & 79.0 & 196 & 20.3 & 7 & .7 \\
\hline 20 & 587 & 60.8 & 324 & 33.6 & 54 & 5.6 \\
\hline 21 & 655 & 67.9 & 282 & 29.2 & 28 & 2.9 \\
\hline 22 & 709 & 73.5 & 204 & 21.1 & 52 & 5.4 \\
\hline Average & 678 & 70.3 & 252 & 26.0 & 35 & 3.7 \\
\hline
\end{tabular}

Majority of the respondents precisely $70.3 \%$ agreed that women who belong to organizations participate more in rural development projects while $26.0 \%$ said no and 3.7 did not know. We conclude that $70.3 \%$ was significant enough to conclude that women who belong to organizations participate more in rural development projects details are as follows.

\subsection{Hypotheses}

This section in chapter four deals with the hypotheses that were stated and tested to find out the position of the premises made and how they could stand.

Hypothesis 1: Rural areas in Enugu State are not optimally developed due to empowerment of men more than women economically.

We proceed to test this hypothesis thus:

$H_{0}$ : Rural areas in Enugu State are more likely not to be developed optimally because of economic empowerment of men than women.

$H_{i}$ : Rural areas in Enugu State are more likely to be developed optimally because of economic empowerment of men than women.

Table-3. To what extent does economic empowerment of women increase women participation in rural development?

\begin{tabular}{l|c|c|c|c}
\hline Variable & \multicolumn{2}{|c|}{ Category of Participation of Women } & Total \\
\hline Levels of discrimination & No Participation & Little Participation & $\begin{array}{c}\text { Average } \\
\text { Participation }\end{array}$ & \\
\hline Extreme economic empowerment & 523 & 150 & 125 & 798 \\
\hline Moderate economic empowerment & 78 & 50 & 23 & 151 \\
\hline No economic empowerment & 10 & 4 & 2 & 16 \\
\hline Total & 611 & 204 & 150 & 965 \\
\hline
\end{tabular}

A further analysis of table above using the $\chi^{2}$ statistical technique produces the result shown in table 15.4.3.3 below:

Table-4. Result of Inferential Statistics using Chi-Square

$\mathrm{X}^{2}$ Results on the Significance of Economic Empowerment of Women Increase Participation in Rural Development.

\begin{tabular}{|c|c|c|c|c|c|c|}
\hline S/No & Question Item & DF & $\mathrm{X}^{2} . \mathrm{cal}$ & $\mathrm{X}^{2}$.crit & Significance & Decision \\
\hline 1 & Inheritance right & 2 & 333.45 & 5.991 & 0.0000 & Reject HO \\
\hline 2 & $\begin{array}{l}\text { Prohibition of violent widowhood } \\
\text { practices }\end{array}$ & 2 & 326.59 & 5.991 & 0.0000 & Reject HO \\
\hline 3 & Membership of co-operation & 2 & 27.97 & 5.991 & 0.0000 & Reject HO \\
\hline 4 & Better education & 2 & 11.90 & 5.991 & 0.0000 & Reject HO \\
\hline 5 & More organized women organization & 2 & 26.04 & 5.991 & 0.0000 & Reject HO \\
\hline 6 & Women empowerment & 2 & 208.14 & 5.991 & 0.0000 & Reject HO \\
\hline 7 & $\begin{array}{l}\text { Equal participation of both men and } \\
\text { women }\end{array}$ & 2 & 155.40 & 5.991 & 0.0000 & Reject HO \\
\hline \multirow[t]{2}{*}{8} & Sharing of family decision making & 2 & 625.10 & 5.991 & 0.0000 & Reject HO \\
\hline & & 2 & 214.32 & 5.991 & 0.0000 & Reject $\mathrm{HO}_{3}$ \\
\hline
\end{tabular}


To test the hypothesis a tabulation of the economic empowerment of women increase participation based on economic empowerment as aggregation of other factors which included inheritance right, prohibition of violent practices, membership of associations, better education, and sharing family decision making. The decision to this was that the alternative hypothesis was accepted with the rejection of the null hypothesis. This is because the calculated $\mathrm{X}^{2}$ values of 214.32 was greater than the critical value of $\mathrm{X}^{2}$ of 5.991.This implies that economic empowerment of women will make Enugu State development optimally because women will engage more in rural development activities.

Hypothesis 2: Membership of women in women organizations and cooperatives are more likely to encourage women participation in rural development

We proceed to test this hypothesis thus:

$\mathrm{H}_{\mathrm{o}}$ : Women who belong to women's organization/co-operations are not more likely to participate in rural development activities than non members.

$\mathrm{H}_{1}$ : Women who belong to women's organization/co-operations are more likely to participate in rural development activities than non members.

Table-5. To what extent does membership of women organizations and cooperatives increase women participation in rural development?

Spread of Respondents showing opinion on Membership of women in women organizations and cooperatives are more likely to increase women participation in rural development.

\begin{tabular}{l|c|c|c|c}
\hline Variable & \multicolumn{2}{|c|}{ Category of Participation of Women } & Total \\
\hline Levels of discrimination & $\begin{array}{c}\text { No } \\
\text { Participation }\end{array}$ & Little Participation & $\begin{array}{c}\text { Average } \\
\text { Participation }\end{array}$ & 64 \\
\hline $\begin{array}{l}\text { Extreme membership } \\
\text { participation }\end{array}$ & 414 & 200 & 678 \\
\hline $\begin{array}{l}\text { Moderate membership } \\
\text { participation }\end{array}$ & 123 & 86 & 43 \\
\hline No membership participation & 15 & 5 & 252 \\
\hline Total & 552 & 291 & 122 & 35 \\
\hline
\end{tabular}

A further analysis of table above using the $\chi^{2}$ statistical technique produces the result shown in table 16.4.3.4 below:

Table-6. Result of Inferential Statistics using Chi-Square.

$\mathrm{X}^{2}$ Results on the Significance on Membership of women in women organizations and cooperatives are more likely to increase women participation in rural development.

\begin{tabular}{|c|c|c|c|c|c|c|}
\hline S/No & Question Item & DF & $\mathrm{X}^{2} . \mathrm{cal}$ & $\mathbf{X}^{2}$.crit & Significance & Decision \\
\hline 1 & $\begin{array}{l}\text { Does your organization participate in } \\
\text { rural development? }\end{array}$ & 2 & 232.23 & 5.991 & 0.0000 & Reject HO \\
\hline 2 & $\begin{array}{l}\text { Do you contribute to the well-being of } \\
\text { your family member? }\end{array}$ & 2 & 561.35 & 5.991 & 0.0000 & Reject HO \\
\hline 3 & Do women have leadership position? & 2 & 412.57 & 5.991 & 0.0000 & Reject HO \\
\hline \multirow[t]{2}{*}{4} & Will you like to serve under a woman? & 2 & 314.75 & 5.991 & 0.0000 & Reject HO \\
\hline & & 2 & 380.22 & 5.991 & 0.0000 & Reject $\mathrm{HO}_{4}$ \\
\hline
\end{tabular}

To test the hypothesis, a tabulation of membership of organizations of women participating in rural development was checked. Based on these questions, does your organization participate in the development of your community was held constant with the aggregate of do you contribute to the well-being of the family, do women have leadership position and would you like to serve under a woman? The result shows that women who belong to organizations aggregated were the major platform for women participating in community development. This decision was taken based on the fact that the calculated $\mathrm{X}^{2}$ of 380.22 was greater than the critical $\mathrm{X}^{2}$ of 5.991. To this effect the alternative hypothesis was accepted with the rejection of the null hypothesis indicated that women who belong to organizations are more likely to participate more in rural development activities. 


\section{CONCLUSION}

With the activities of feminists, awareness campaigns, education, empowerment, the position of women in most communities have been challenged and some of the old notion of women as house wife, disinheritance, violent widowhood practices have been challenged. The result is that today it is no longer ideal for anybody to accept to be a full time house wife, Igbo women can now inherit from their father's personal properties. Married women have come to challenge the house-wife syndrome by answering one who arranges wealth (Odoziaku) while others answer those who make money with their husbands (Osodiakpaku).

All associations in the community are interested in community development; any association that is not interested in community development is not relevant in the community. The most frequently mentioned projects embarked upon in the selected communities include:

1. Women's housing projects that address the particular needs of women or women headed household through thrift.

2. Contribution for the purposes of electrification and purchase of transformers.

3. $\quad$ Construction and maintenance of small bridges across towns.

4. Pulling resources together and establish a garri processing industry.

5. Rendering service to the poor and needy.

6. Establishment or maintenance of nursery, primary and secondary schools.

7. Vocation Centres for women - shoes, bags, dress and hair plaiting.

8. Construction and maintenance of town halls.

9. $\quad$ Construction and maintenance of customary court houses.

10. Construction and maintenance of village roads.

11. Building or maintenance of maternity homes, e.t.c.

Sustainable rural development can only be achieved through equal participation of both men and women in community development programmes after the removal of all cultural barriers against women which include: lack of inheritance rights, exclusion of women in decision making, lack of economic empowerment. These are the major reasons for the inadequate participation of women in rural development projects. Women face institutional challenges like denial of bank loans to them because many of them hardly have collateral (land). Though this problems was solved in most communities by women joining co-operative societies registered by the government and guaranteed by group solidarity. Successive governments have done one or two things for the upliftment of women in the communities like $35 \%$ affirmative action in all employments, granting of inheritance right to Igbo women, prohibition of violent widowhood practices, outlawing teenage marriage. Many parents no longer participate in the vagina mutilation of their daughters. These were achieved because of public awareness campaigns. Happily today in Enugu State the education of the girl child has received considerable attention. Today in Enugu State there are more girls than boys in the secondary and tertiary institutions.

\section{RECOMMENDATIONS}

Government at all levels should stimulate the rural people to enhance the so-called self-help type of rural development. If the initiative for development is not forth coming, from members of the community concerned, then government can stimulate interest by using enlightenment campaign, the initiation of project and financial incentive for specific projects (Aguene, 2003).

The Supreme Court was right to have voided that aspect of Igbo native law and custom that denies female children inheritance, especially of estates located in their home town and villages. The recent bill passed by the past $7^{\text {th }}$ senate banning all unjust practices against widows, making widows custodians of their late husbands property. The bill went further to give women the right to bail or stand as sureties in the Court. It also makes it compulsory to reserve $35 \%$ of all employments for women. 
Women entrepreneurship training should be intensified and more encouragement from the government and other bodies according to womenfolk. This will remove the house wife syndrome. It is no longer useful for somebody to play the role of a house wife in contemporary Nigeria. Everybody must contribute towards rural development. Women should be economically empowered because economic empowerment leads to other empowerments- social, political and otherwise. Women should stop the idea of waiting to receive their rights promised them but go out to get them (Akande, 1987).

Funding: This study received no specific financial support.

Competing Interests: The author declares that there are no conflicts of interests regarding the publication of this paper.

\section{REFERENCES}

Adebisi, J., \& Ademola, A. (2014). Towards improving local government administration on the rural poor in Nigeria. The role of women in private media. African Journal of Sustainable Development, 10(6), 88-100.

Aderson, P. (2009). Introduction to sociology. New York: McGraw Hills Inc.

Adigwe, C. (1982). Rural development problems and strategies for improvement. International Labour Review Gevana, 108, 46-52. Aguene, I. N. (1998). Rural $S \neg$ ociology: An African perspective. Nuskka: Prize Publishers.

Aguene, I. N. (2003). Theoretical framework of rural development in Nigeria. Journal of Management and Social Science, 12(2003), $122-128$.

Aguene, I. N. (2004). Basic sociological theories. Abakaliki: Illoabuchi Printing and Publishing Company.

Akanda, J. (2009). Gender responsive governors for sustainable development University of Benin Centre for gender studies Benin: Uniben Press.

Akande, E. (1987). The situation of rural women in Nigeria. The Nigeria Rural Sociologist, 2(13), 4-8.

Arisi, A., \& Agbure, G. (2010). Gender equality factor in the teaching of social studies and sustainable development in Nigeria. Benin Journal of Genders Studies, 2(1), 169-177.

Berger, C. (1963). Introduction to sociology. New York: Mac Graw Hills Publishes.

Borley, S. (1971). In Blalock (1983). Social statistics international students edition. New York: Mac Graw Hill.

China Today. (1995). Quoted in Sofia A (2010). The recognition of human rights of African workers. International Journal of Advanced Legal Studies and Good Governance, 1(1), 25-45.

Dokpesi, A. O., \& Ibezugbe, A. (2010). Non-participating development as root cause of underdevelopment of the Niger Delta Region of Nigeria. South-South Journal of Cultural and Development, 12(2), 10-12.

Hinawi, P. (1991). Rural development problems in Africa some lessons from Western Nigeria. Canadian Geiger, 2(3), $250-267$.

Idriss, J. (1992). The state of world rural poverty. Rome: Art. Grafichs Fratelli Palombi.

Ilo, E. (2005). The challenges for growing small scale industry Geneva: Ilo Publication.

Ilogu, E. (1974). Christianity and igbo culture. New York: Nok Publishers.

Inhabekhai, C. I. (2010). Management of community development programme and projects. Benin: Uniben Press.

Justice Development and Peace Commission. (1998). Popular participation in development. Training Manual Ijebu-Ode JDPC, Catholic Diocese of Ijebu-Ode, 1(1), 10-14.

Krishmaswany, C. (2005). Quoted in Maduabum (2007) Fundamentals of educational research: Owerri Versatile Publishers.

Mabonje, A. I. (1991). Women in business and agriculture in Nigeria monograph. Ibadan: Wallet Press.

Macionis, J. (2015). Sociology tent edition New Delhi prepro India ltd

Mansuri, A., \& Roa, B. (2004). Rural development in Nigeria: Ilo Ife University Press.

National Gender Policy. (2000). Abuja federal ministry of women affairs and social development.

National Gender Policy. (2006). Abuja federal ministry of women affairs and social development.

Ntunde, F. (2004). Development of agricultural economics and extension. An analysis of sources of information on improved farming practices. A Study of Women Farmers in Enugu State ESUT Enugu. Unpublished PhD Dissertation. 
Nwankwo, E., \& Ezeh, J. (2007). Towards improved integrated rural development in Nigeria. Journal of Political and Administrative Studies. Published by the Department of Political Science and Public Administration in Ebonyi State, University of Abakaliki, 3(1), 10-14.

Nweze, T. (2011). Investing in women: A sure foundation for future development. Ebonyi State University Journal of Society, 1(2), 99-105.

Nyerere, J., Mfune, O., Fuh, D., Sulemana, N., Mutisya, E., Yiran, G., . . Odingo, A. (2014). The role of higher education in building a sustainable African society in African. Journal of Sustainable Development, 4(3), 15-35.

Obi, R. (2010). Gender and society. Benin: Sylva Publishing Ltd.

Oduara, A. R. (1994). An Introduction to community development. Benin: University of Benin Press.

Okeyo, A. P. (1979). African women in changing rural economies. The Courier, 30(57), 63-65.

Okonkwo, E. A. (2013). Attitudes towards gender equality in South-Eastern Nigeria culture: Impact of gender culture and level of education. Gender and Behaviour, 11(2), 5579-5585.

Olabode. (2012). Press release-UN general assembly's open working group proposes sustainable development goals. Sustainable Development.un.org. 19 July 2012. Retrieved 2018-07-12.

Olakorotu. (2013). The creation of patriarchy. New York: Oxford University.

Olisa, M., \& Obiuku, J. (1992). Rural development in Nigeria. Dynamics and strategies: Awka Mekslink Publishers.

Onah, F. (2011). Poverty alleviation strategies in Nigeria. The Ebonyi State experience. Ebonyi State UniversityJournal of Society, $1(4), 76-82$.

Onokerhoraye, A., \& Okafor, C. (1994). Rural development and planning for Africa. Benin City: Uniben Printing Press.

Onwe, F. (2008). The relevant of feminism for women studies Ebonyi State University. Journal of Sociology, 2(2), 1-11.

Otite, O., \& Ogionwo, W. (1979). An introduction to sociological studies. Ibadan: Heinemann Educational Books Ltd.

Owen, C. (2001). Gender issues in contemporary African. Education Nairobi, 8(10), 81- 96.

Thorton, D. S. (1982). Success or failure in rural development efforts. Calabar Community Development Journal, 2(2), 12-14.

Towards Earth Summit. (2001). United nations world conference on environment. New York: United Nation Publication.

UN Conference on Women. (1995). Bejin China Conference Proceedings.

UNAPC. (1997). Report on women's involvement in computer networking around the world. New York: United Nations Publication.

UNESCO. (2004). Quoted in Onyshi T. 2010 Nigeria A Hand Book of Good Governance Enugu John Jacobs Classical Publishers.

United Nations. (2008). Integral approach to rural development in Africa. New York: UN Social Services for Africa.

United Nations Education Scientific and Cultural Organization UNESCO. (1995). World summit for social development New York United Nation Publications.

Wallace, R., \& Wolf, A. (1982). Contemporary sociological theories: Continuum the classical tradition new Jersey. New Jersey: PrenticeHill Inc.

World Bank. (1995). World development report making services Work for the Poor Washington DC: World Bank.

Zinn. (2005). Gender and resources management households and groups strategies and transitions. Agriculture and Human Value, $18(1), 5-9$.

Views and opinions expressed in this article are the views and opinions of the author(s), International Journal of Sustainable Development E World Policy shall not be responsible or answerable for any loss, damage or liability etc. caused in relation to/arising out of the use of the content. 